\title{
CUSTOMER ENGAGEMENT IMPACTS TOWARDS PURCHASE INTENTIONS IN THE ONLINE TRAVEL AGENT INDUSTRY
}

\author{
Carolin, Gabriel Jessye, Isaiah Abib, Michael Laurel, Nicks Candra Putra \\ Universitas Prasetiya Mulya, Jakarta Selatan \\ carolin.carolin@student.pmbs.ac.id \\ gabriel.gonsoomer@student.pmbs.ac.id \\ isaiah.dharma@student.pmbs.ac.id \\ nicks.putra@student.pmbs.ac.id \\ michael.laurel@student.pmbs.ac.id
}

\begin{abstract}
This study attempts to investigate the effect of customer engagement which represented through surveillance, social interaction, sharing information, attraction, and social influence on OTA's (Online Travel Agency) customer engagement in social media such as Facebook, Twitter, and Instagram about its connection to purchase intention. The importance of this research is to understand the customer engagement level necessary to satisfy the needs of social media users that can lead to purchase intentions. The questionnaires used convenience sampling with totals of 30 questions and 200 respondents within the scope of Java Island Indonesia. Partial Least Square was used to analyze the data and six hypotheses were tested with five independent variables which are surveillance, social interaction, sharing information, attraction, and social influence. One mediating variable which is customer engagement, and one dependent variable purchase intention. The findings of this research are showing that OTAs are better if they focus on social influence, social interaction, and sharing information to increase customer engagement and ultimately create the intention to purchase for customers.
\end{abstract}

Keywords: Social Media, Customer Engagement, Purchase Intention, Online Travel Agency (OTA)

\section{ABSTRAK}

Penelitian ini berusaha untuk menyelidiki pengaruh keterlibatan pelanggan yang diwakili oleh pengawasan, interaksi sosial, pertukaran informasi, daya tarik, dan pengaruh sosial atas keterlibatan pelanggan Agen Perjalanan Online (OTA) di media sosial seperti Facebook, Twitter, dan Instagram serta hubungannya dengan niat beli. Pentingnya meneliti hal ini adalah untuk mengerti tingkat keterlibatan pelanggan yang dibutuhkan untuk memenuhi kebutuhan pengguna media sosial dan bisa membawa kepada niat beli. Penyebaran kuesioner menggunakan teknik convenience sampling dengan total 30 pertanyaan dan diisi oleh 200 responden di wilayah Pulau Jawa Indonesia. Analisis data menggunakan Partial Least Square dan enam hipotesis diuji dengan lima variabel independen yaitu pengawasan, interaksi sosial, berbagi informasi, daya tarik, dan pengaruh sosial. Satu variabel mediasi yaitu customer engagement, dan satu variabel dependen niat beli. Temuan penelitian menunjukkan bahwa Agen Perjalanan Online (OTA) lebih baik jika fokus pada pengaruh sosial, interaksi sosial, dan berbagi informasi untuk meningkatkan keterlibatan pelanggan dan pada akhirnya menciptakan niat untuk membeli bagi pelanggan.

Kata Kunci: Media Sosial, Keterlibatan Pelanggan, Niat Beli, Agen Perjalanan Online (OTA)

\section{INTRODUCTION}

In this era of globalization, social media has been one of the most trusted sources of news. People are depending on how fast they can get updates of what is happening not only around their environment of living but around the world. It is quite easy for someone to know any kind of information and knowledge they want to achieve even if it comes from the other side of the world. The rapid growth of civilization is also affected by this swift step of technology and information sharing on the internet through social media. In such a short period of time, people have limited yet still growing total numbers of social media they can use unknowingly (Schroeder, 2016).

This phenomenon, of course, has become the new avenue to explore. Business owners also see this as a room for even more chances and expanding their businesses. There is one more trend that encourages people to be aware of the world's growth and it is traveling. These days people travel everywhere without any 
inconvenience. Online Travel Agency (OTA) was an alternative for getting plane tickets and for booking a hotel room but now it turned into the first thing that comes to people's minds. Google Trends saw a 20 percents rise in searches for Online Travel Agencies including Traveloka, Tiket.com, and Pegipegi (Jakarta Post, 2019).

Based on the previous research by Yoong \& Lian (2019) about Customer Engagement in Social Media and Purchase Intentions in the Hotel Industry, this research adopted the variables used and modified it. There is a gap between the level of customer engagement that OTA has been doing right now and the level of customer engagement that is expected by the social media users. There is also a limitation according to the previous research, the social media used as a medium for the research is only Facebook. There are a few factors affecting the customer engagement in social media and those are types of content, types of media, and posting period (Cvikikj and Michahelles, 2013); Social benefit, economic benefit, social enrichment, and entertainment (Gummerus, Veronica, Weman and Pihlström, 2012).

This research is important because we seek to know the effective level of customer engagement is needed in social media so it will increase the purchase intentions of customers and potential customers. Then, because of the limitations from previous research such as the difference in the total of independent variables affecting the dependent and also the social media used as a medium was only Facebook while now Twitter and Instagram have become one of the biggest social media platforms to share information as well. Therefore, the main goals of this research are; 1) To see the impact of Surveillance, social interaction, sharing information, attraction, and social influence on customer engagement on Instagram and 2) To analyze the effect of customer engagement on Instagram to OTA Industry. The independent variables used in this research represent the activity happening in social media such as Facebook, Twitter, and Instagram. Customer engagement becomes the mediation variable because by looking at the level of the engagement, you can see how the communication is going on between the OTA and the customers. Lastly, this research wants to see how much customer engagement in social media affects the purchase intentions of OTA.

The result of this research is expected to be beneficial to OTA Industry in their social media marketing strategies.

\section{CONCEPTUAL FRAMEWORKS}

\section{Social Influence}

According to (Bandura, 1986) social influence could also take the form of vicarious learning through observing other people's experiences. The process framework of social influence is initiated by Kelman (1958) in which suggestions are made by others, especially those who frequently use specific social media and have a positive view of it, could be a consideration to customer to choose a specific online service (Aronson, Timothy, \&Akert, 2010; Chiu, Cheng, Huang, \& Chen, 2013). Currently, the appearance of social media allows lots of people to upload their content, and by doing so they can influence others and are being influenced themselves. A form of virtual environment offers a new viewpoint for the existing social influence theories (Snijders and Helms, 2014). Poirier and Cobb (2012) assert that social influence can provide a solution to the problem of poor engagement and adherence to intervention as planned. This research explores to what the extent of persuasive social influence alters customer behavior toward engagement, the hypothesis below will be discussed:

H1: Social Influence in social media has a positive effect on customer engagement.

\section{Surveillance}

Whiting and Williams (2013) defined social media played a major role in obtaining information and self-education which is better known as surveillance. Another definition, social media surveillance refers to the collection and processing of personal data collected from digital communication channels, often by automated technology that enables vast quantities of 
information and content to be aggregated, processed, and analyzed in real-time (Shahbaz and Funk, 2019). The social media interaction itself is a widely used means of creating and publishing information openly through the internet. Consumers are engaging in social media to satisfy their information needs according to (Brodie, Ilic, Juric, and Hollebeek, 2013). Information that is classified as high quality made the interaction between customers feel worthwhile (Gummerus, Veronica, Weman, and Pihlstorm, 2012). Information found in social media offers new opportunities for surveillance and engagement (Humphreys and Wilken, 2015). Therefore, the following hypothesis in this regard will be examined:

$\mathrm{H}$ 2: Surveillance in social media has a positive effect on customer engagement.

\section{Social Interaction}

According to (Whiting and Williams, 2013), social interaction is a motive to interact and socialize with others with social media as a platform. Social gratification plays a crucial role for consumers who are inspired to use the internet to communicate, access, and engage with other users on the network (Stafford and Stafford, 2001). Jeffrey A. Hall (2018) found that occasionally, social media use and social interaction co-occurred, however just $2 \%$ of social interaction occurred through social media. Social interactions via social media were typically based on chatting, one-on-one conversations with closer relationship partners and information exchanged with acquaintances were seldom undifferentiated, transmitted, or passively consumed. Yet, other studies have suggested that the measure of online social interaction prompts more visits to the brand's site (McCulloch, 2014) and long term dependence on social media contributes to long term benefit for increasing market share and improved performance for any business entity (Malhotra et al., 2013; Ngai et al., 2015).

Then, to test the relationship between social interaction and customer engagement in social media, the following hypothesis is formed:
H3: Social Interaction in social media has a positive effect on customer engagement

\section{Sharing Information}

Sharing information can be interpreted as 'a collection of actions by which information is provided to others, either proactively or on request, so that information has an effect on the image of other people of the world ... and produces a similar or mutually beneficial view of the world ' (Sonnenwald, 2006). Ridings and Gefen (2006) found that people primarily enter digital communities to seek information, social support, friendship, and recreation. By utilizing social media or digital platform communities, users are offered opportunities to interact more with people of strong ties than those of the weak ones (Thoumrungroje, 2014). On the other hand, intentional collection and exchange of information help to improve user-to-user relations (Marsh et al., 2009) and increased customer engagement (Osatuyi, 2013). This research will only focus on Instagram as the main social media platform to be analyzed further. Hence, the following hypothesis in this regard will be examined:

H4: Sharing information on social media has a positive effect on customer engagement.

\section{Attraction}

Oxford defined attraction as the action or power of evoking interest, pleasure, or liking for someone or something. In general, word attraction has the characteristic of pulling or drawing someone or something closer. Taylor (2019) defined Attraction Marketing as bringing people to you rather than going after them. Araujo and Neijens (2012) stated that users who are attracted to a company's pages are more likely to engage with them by liking, sharing, and commenting. According to Fortin and Dholakia (2005), previous studies show that a high degree of vividness tends to be most effective in improving attitudes towards a website and increasing clickthrough rates which are regarded as engagement behavior (Lohtia, Donthu, and Yaveroglu, 2007). Vividness is to what degree a brand post activates various senses (Steuer, 1992). Therefore, multimedia content has the power to influence 
consumers because of its strong effect on various senses (Coyle and Thorson, 2001). This research will only use Instagram as the material to be analyzed. The following hypothesis will be proven through the completion of this research.

H5: Attraction in social media has a positive effect on customer engagement.

\section{Customer Engagement}

Bowden (2009) claimed that customer engagement is a psychological process that has shaped the underlying consumer loyalty pattern from the brand's new customers, as well as the mechanism by which customer loyalty can be sustained for repeated brand purchases. Brodie (2013) defined consumer engagement as: "A multidimensional concept comprising cognitive, emotional, and/or behavioral dimensions, and plays a central role in the process of relational exchange where other relational concepts are engagement antecedents and/or consequences in iterative engagement processes within the brand community". Consumer engagement is the brand concept or media that the customer has encountered and leaves a favorable impression on the brand (Cumming, 2007). The increased mass utilization of social media drives the perception that social media is a critical tool in supporting customer engagement (Pütter, 2017). Because of the interactive and innovative nature of social media, the effects of customer engagement can be seen in social media indicators such as approval expressions, scores, feedback, and shares (Barger and Labrecque, 2013). In this research, the engagement discussed is the engagement before the purchase occurred.

H6: Customer engagement has a strong impact on purchase intention.

\section{Purchase Intention}

Purchase Intention is the probability of the consumer's willingness to take particular purchase behavior (Zheng, 2015). Dodds et al (as cited in Zheng, 2015) also noted that purchase intention refers to subjective probability for a consumer to buy a particular product. According to The Theory of Reasoned Action by (Fishbein and Ajzen, 1975), predicting purchase behavior can be simplified by measuring customer's purchase intentions (Peter and Olson, 2009). Mirabi, Akbariyeh \& Tahmasebifard (2015) stated that purchase intention is somewhat similar to decision making whereby consumers demonstrate their likelihood, willingness, or plan to purchase certain brands. Anubha and Jain (2016) also explained that purchase intentions are formed in favor of a company's products only when customers feel engaged with the company. Customer engagement is needed to predict purchase intention, but this claim must be proven. This research will prove the relationship between customer engagements in social media toward purchase intention by the following hypothesis.

\section{METHODOLOGY}

\section{Research design, sampling, measurement}

A research design is established to determine, among other matters, how to obtain further data, evaluate and interpret them, and eventually, to provide a solution to the problem (Sekaran, 2003). For this research, the quantitative method is used to determine causality between the variables. To maintain objectiveness and effectiveness within this research, the quantitative approach was chosen and the statistical model was used to explain the object of observation. In order to yield meaningful and precise consumer behavior, a large sample of Instagram users is required for this observation. From the resulting samples, the researcher generalizes the population or draws the inferences (Creswell, 2014).

The population that was used in this research are male and female with an average age of 25 years old and have an Instagram account. Instagram is used as the main social media platform because the majority of the Online Travel Agency (OTA) put most of its marketing content and promotion campaign on Instagram. According to (Muthen and Muthen, 2002) a minimum sample size of 150 shall be required to perform Structural Equation Modeling (SEM), therefore the researcher has decided to use 200 samples to meet the requirement to perform SEM analysis. Before the survey was spread, the researcher had conducted a pilot test with 10 
respondents to make sure all the questions were clear. Probability sampling was used to involve random selection, allowing the researcher to make statistical inferences about the whole group. The survey consists of 36 questions and assessed using a Likert scale ranging from one (strongly disagreed) to six (strongly agreed) to measure social influence, surveillance, social interaction, sharing information, attraction, customer engagement, and purchase intention. Meanwhile as shown in table 2 that some of the questions were erased due to validity and reliability reason. To perform validity and reliability analysis, the researcher used SmartPLS software version 3.0.

The questionnaire used in this research was modified from Yoong \& Lian, 2019. The reason for the modification is because of the variable added which is Social Influence. Also the difference in demographic and cultural factors between countries of origin.

\section{Profile of respondent}

This research using a total of 239 respondents, 97.5\% have Instagram applications and $84.9 \%$ have seen OTA's Instagram. $64.5 \%$ of them have seen Traveloka's Instagram \& 26.1\% seen Tiket.com's. Furthermore, 109 of the

Table 1. Convergent Validity

\begin{tabular}{|l|l|l|}
\hline \multicolumn{1}{|c|}{ Variables } & $\begin{array}{c}\text { Composite } \\
\text { Reliability }\end{array}$ & \multicolumn{1}{c|}{$\begin{array}{c}\text { Average } \\
\text { Variance } \\
\text { Extracted } \\
\text { (AVE) }\end{array}$} \\
\hline $\begin{array}{l}\text { Attraction } \\
\text { (ATR) }\end{array}$ & 0.848 & 0.651 \\
\hline $\begin{array}{l}\text { Customer } \\
\text { Engagement } \\
\text { (CUE) }\end{array}$ & 0.872 & 0.631 \\
\hline $\begin{array}{l}\text { Purchase } \\
\text { Intention (PIN) }\end{array}$ & 0.919 & 0.740 \\
\hline $\begin{array}{l}\text { Sharing } \\
\text { Information } \\
\text { (SHR) }\end{array}$ & 0.863 & 0.611 \\
\hline $\begin{array}{l}\text { Social Influence } \\
\text { (SIN) }\end{array}$ & 0.829 & 0.619 \\
\hline $\begin{array}{l}\text { Social } \\
\text { Interaction } \\
\text { (SIR) }\end{array}$ & 0.876 & 0.640 \\
\hline $\begin{array}{l}\text { Surveillance } \\
\text { (SUR) }\end{array}$ & 0.853 & 0.592 \\
\hline
\end{tabular}

respondents are male and 94 are females. The age range of the respondents falls between 18 for the youngest and 50 for the oldest, while most of them are 24-25 years old. $51.2 \%$ of the respondents live in Jakarta, followed by $19.2 \%$ who live in Bogor, Depok, Tangerang, and Bekasi area; and $16.3 \%$ live in Bandung.

\section{RESULT}

\section{Validity and Reliability}

Validity and reliability testing are mandatory and necessary to test how well that is developed measures the concept it is intended to measure. Before analyzing the structural model. First, there are two kinds of validity tests used in PLS-SEM: Discriminant Validity and Convergent Validity. Table 1 shows the result of Average Variance Extracted (AVE) used for convergent validity. The calculation shows the number compared to the validity necessity value. For AVE in PLS-SEM, if the value is 0.5 or higher, it means the variable is valid (Ghozali \& Latan, 2015). As shown in Original Sample (O) the number of AVE of each variable is above 0.5 meaning all the variables used in this research are valid.

After looking through the Average Variance Extracted to determine the convergent validity, next to see the discriminant validity the value of each indicator of their respective variables must be higher than other variables' value and must be higher than 0.6. As seen in Table 2 below, all values of cross-loadings toward construct is higher than 0.60 . It concludes that there is no problem with discriminant validity.

Next in Table 3 below shows the result of the composite reliability test and according to Ghozali and Latan (2015), the value of a variable should be higher than 0.7 to be reliable. All variables used can be seen having higher value than 0.7 in Original Sample (O) meaning all variables are reliable. 
Table 2. Discriminant Validity

\begin{tabular}{|c|c|c|c|c|c|c|c|}
\hline Variables & Attraction & $\begin{array}{c}\text { Customer } \\
\text { Engagement }\end{array}$ & $\begin{array}{l}\text { Purchase } \\
\text { Intention } \\
\end{array}$ & $\begin{array}{c}\text { Sharing } \\
\text { Information }\end{array}$ & $\begin{array}{c}\text { Social } \\
\text { Influence }\end{array}$ & $\begin{array}{c}\text { Social } \\
\text { Interaction }\end{array}$ & Surveillance \\
\hline ATR_1 & 0.852 & 0.442 & 0.454 & 0.615 & 0.421 & 0.341 & 0.559 \\
\hline ATR_3 & 0.719 & 0.181 & 0.361 & 0.392 & 0.272 & 0.320 & 0.409 \\
\hline ATR_4 & 0.843 & 0.331 & 0.377 & 0.416 & 0.254 & 0.335 & 0.414 \\
\hline CUE_1 & 0.395 & 0.771 & 0.510 & 0.408 & 0.387 & 0.282 & 0.434 \\
\hline CUE_3 & 0.361 & 0.842 & 0.462 & 0.349 & 0.461 & 0.421 & 0.354 \\
\hline CUE_4 & 0.199 & 0.772 & 0.370 & 0.275 & 0.444 & 0.433 & 0.256 \\
\hline CUE_5 & 0.383 & 0.790 & 0.619 & 0.498 & 0.376 & 0.333 & 0.356 \\
\hline PIN_1 & 0.455 & 0.582 & 0.845 & 0.547 & 0.427 & 0.431 & 0.449 \\
\hline PIN_2 & 0.391 & 0.541 & 0.848 & 0.451 & 0.387 & 0.376 & 0.386 \\
\hline PIN_3 & 0.421 & 0.570 & 0.879 & 0.523 & 0.421 & 0.408 & 0.468 \\
\hline PIN_4 & 0.444 & 0.448 & 0.867 & 0.483 & 0.400 & 0.431 & 0.370 \\
\hline SHI_1 & 0.460 & 0.372 & 0.427 & 0.758 & 0.292 & 0.338 & 0.496 \\
\hline SHI_2 & 0.401 & 0.423 & 0.507 & 0.774 & 0.372 & 0.456 & 0.433 \\
\hline SHI_3 & 0.474 & 0.322 & 0.442 & 0.780 & 0.149 & 0.240 & 0.556 \\
\hline SHI_4 & 0.579 & 0.406 & 0.447 & 0.815 & 0.246 & 0.329 & 0.546 \\
\hline SIN_1 & 0.357 & 0.416 & 0.426 & 0.260 & 0.825 & 0.362 & 0.201 \\
\hline SIN_2 & 0.226 & 0.449 & 0.273 & 0.203 & 0.820 & 0.424 & 0.214 \\
\hline SIN_3 & 0.396 & 0.361 & 0.448 & 0.380 & 0.710 & 0.330 & 0.384 \\
\hline SIR_1 & 0.281 & 0.347 & 0.363 & 0.314 & 0.401 & 0.791 & 0.293 \\
\hline SIR_2 & 0.325 & 0.338 & 0.331 & 0.319 & 0.315 & 0.758 & 0.277 \\
\hline SIR_3 & 0.360 & 0.331 & 0.362 & 0.366 & 0.376 & 0.833 & 0.404 \\
\hline SIR_4 & 0.334 & 0.430 & 0.454 & 0.410 & 0.418 & 0.815 & 0.363 \\
\hline SUR_1 & 0.459 & 0.366 & 0.384 & 0.488 & 0.320 & 0.345 & 0.769 \\
\hline SUR_2 & 0.418 & 0.300 & 0.411 & 0.557 & 0.202 & 0.281 & 0.772 \\
\hline SUR_4 & 0.419 & 0.310 & 0.277 & 0.443 & 0.152 & 0.271 & 0.731 \\
\hline SUR_5 & 0.488 & 0.384 & 0.428 & 0.504 & 0.313 & 0.377 & 0.804 \\
\hline
\end{tabular}

Table 3. Composite Reliability

\begin{tabular}{|l|c|c|}
\hline \multicolumn{1}{|c|}{ Variables } & Composite Reliability & Average Variance Extracted (AVE) \\
\hline Attraction (ATR) & $\mathbf{0 . 8 4 8}$ & 0.651 \\
\hline Customer Engagement (CUE) & $\mathbf{0 . 8 7 2}$ & 0.631 \\
\hline Purchase Intention (PIN) & $\mathbf{0 . 9 1 9}$ & 0.740 \\
\hline Sharing Information (SHR) & $\mathbf{0 . 8 6 3}$ & 0.611 \\
\hline Social Influence (SIN) & $\mathbf{0 . 8 2 9}$ & 0.619 \\
\hline Social Interaction (SIR) & $\mathbf{0 . 8 7 6}$ & 0.640 \\
\hline Surveillance (SUR) & $\mathbf{0 . 8 5 3}$ & 0.592 \\
\hline
\end{tabular}




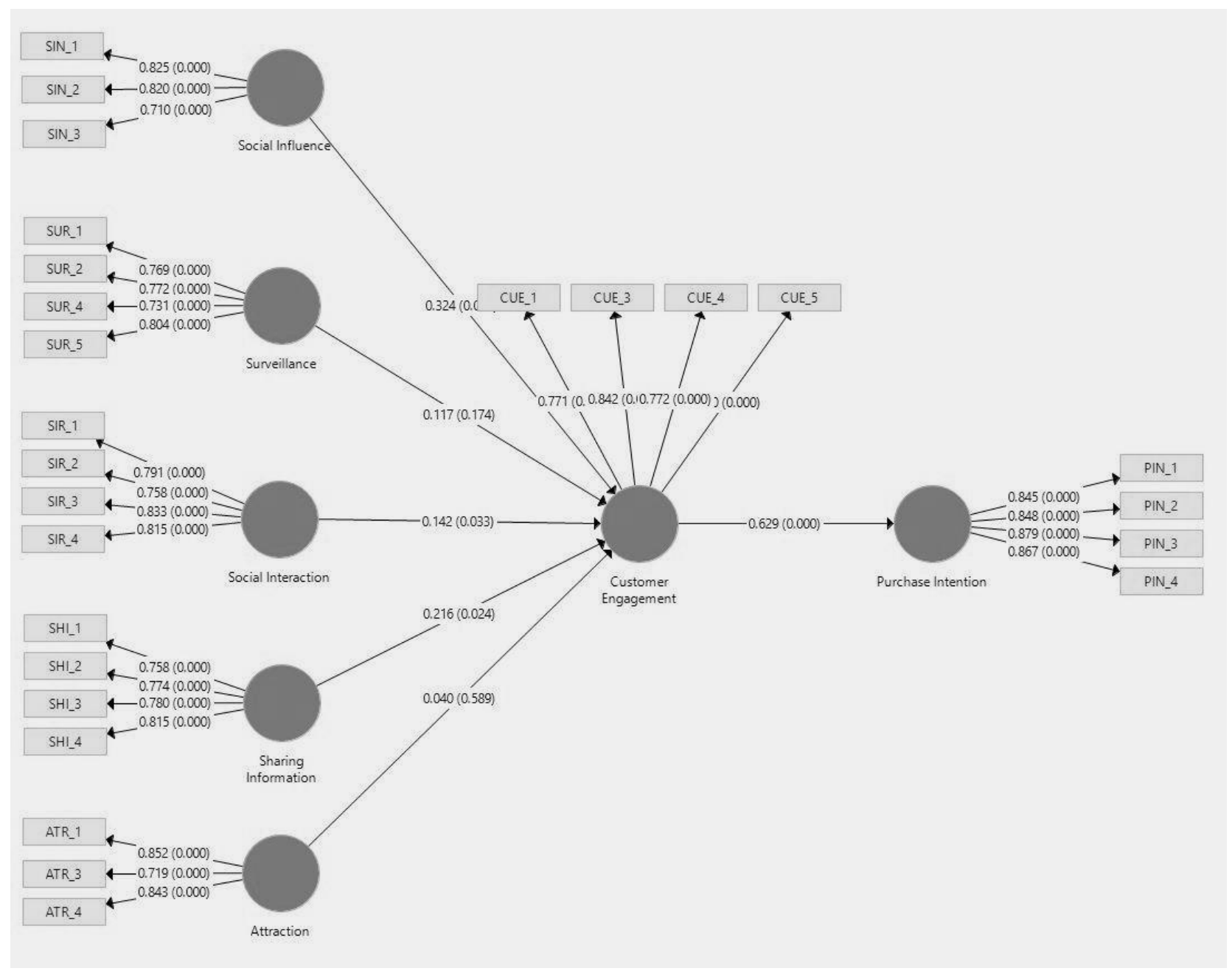

Figure 1. Model Causality

\section{Model Causality Testing}

The final structural model used in this research can be seen in figure 1 . There are five dependent variables, which are social influence, surveillance, social interaction, sharing information, and attraction. Next, there is one mediating variable, customer engagement. Last, there is one dependent variable purchase intention. There are a few indicators eliminated from the first model by reason of validity and reliability testing at the pre-test stage.

Since there is a slight difference between PLS-SEM and SPSS, for this research to see the model causality, we can look at the P-values in table 4. According to Ghozali and Latan (2015), the p-value should be below $5 \%$ or 0.05 to be significant. In the context of this research, the Pvalues show how significant the level of independent variables affecting the mediating variable and the mediating variable affecting the dependent variable. First, we look at social influence to customer engagement $\mathrm{p}$-value of 0.000 and it is below 0.05 meaning it is positively significant and $\mathrm{H} 1$ is accepted. For $\mathrm{H} 2$ about surveillance to customer engagement, the p-value is 0.174 meaning it is not significant and $\mathrm{H} 2$ is rejected. Next social interaction to customer engagement has a p-value of 0.033 and considered as positively significant and $\mathrm{H} 3$ is accepted. $\mathrm{H} 4$ is also accepted and positively significant looking at the p-value of 0.024 for sharing information to customer engagement. Then attraction to customer engagement does not have a significant effect with a p-value of 0.589 and $\mathrm{H} 5$ is rejected. Lastly, customer engagement is positively significant to purchase intention with a p-value of 0.000 and $\mathrm{H} 6$ is accepted. 
Table 4. Path Coefficients

\begin{tabular}{|c|c|c|c|c|c|}
\hline Variables & $\begin{array}{l}\text { Original Sample } \\
\text { (O) }\end{array}$ & \begin{tabular}{|c|} 
Sample Mean \\
(M)
\end{tabular} & $\begin{array}{c}\text { Standard Deviation } \\
\text { (STDEV) }\end{array}$ & P Values & Hypothesis \\
\hline Attraction @Customer Engagement & 0.040 & 0.042 & 0.074 & 0.589 & H5 : Rejected \\
\hline $\begin{array}{l}\text { Customer Engagement } \odot \text { Purchase } \\
\text { Intention }\end{array}$ & 0.629 & 0.629 & 0.040 & $\mathbf{0 . 0 0 0}$ & H6 : Accepted \\
\hline $\begin{array}{l}\text { Sharing Information } \odot \text { Customer } \\
\text { Engagement }\end{array}$ & 0.216 & 0.217 & 0.095 & 0.024 & H4 : Accepted \\
\hline $\begin{array}{l}\text { Social Influence } \otimes C u s t o m e r \\
\text { Engagement }\end{array}$ & 0.324 & 0.326 & 0.070 & 0.000 & H1 : Accepted \\
\hline $\begin{array}{l}\text { Social Interaction } \otimes \text { Customer } \\
\text { Engagement }\end{array}$ & 0.142 & 0.139 & 0.066 & 0.033 & H3 : Accepted \\
\hline $\begin{array}{l}\text { Surveillance } \odot \text { Customer } \\
\text { Engagement }\end{array}$ & 0.117 & 0.120 & 0.086 & 0.174 & H2 : Rejected \\
\hline
\end{tabular}

\section{DISCUSSION}

There are several findings regarding this research about OTA's social media customer engagement effectiveness affecting customer purchase intention. First, there are a few variables that affect customer engagement on OTA's social media account such as Facebook, Twitter, and Instagram. Social Influence with a p-value of 0.000 is the most significant variable affecting customer engagement and $\mathrm{H} 1$ is accepted. This construct is considered effective in stimulating customer engagement in social media. Surveillance has a p-value of 0.174 meaning it is not significantly affecting the customer engagement and $\mathrm{H} 2$ is rejected. Social interaction has a p-value of 0.033 meaning it is positively significant and $\mathrm{H} 3$ is accepted. Sharing information has a p-value of 0.024 meaning it is positively significant and $\mathrm{H} 4$ is accepted. Both social interaction and sharing information have a weak effect on customer engagement even though it is significant. Hence, these two constructs can be improved by OTA services. The attraction has the lowest p-value of 0.589 meaning it is not significant to customer engagement and $\mathrm{H} 5$ is rejected. This could mean that customers are not attracted and satisfied with the content of OTA's social media on Instagram. Lastly, we can conclude that customer engagement has a very important role in increasing the purchase intention of OTA in Indonesia. This statement can be seen from Table 4 where the p-value of customer engagement to purchase intention is 0.000 meaning it is positively significant, therefore, H6 is accepted. This statement also supports previous research by Yoong \& Lian, (2019).

\section{CONCLUSION}

This study examined to what extent each of the five variables of customer engagement (surveillance, social influence, sharing information, social interaction, and attraction) affects purchase intention of Online Travel Agency services in Indonesia. As a result, there is no doubt at this time that social media has an impact on customer engagement, where customer engagement itself has a positive relationship with purchase intention especially in the Online Travel Agency industry in Indonesia. Hence, an Online Travel Agency company should enhance the social influence, sharing information and social interaction aspect for greater purchase intention of customers. Social influence has high significance towards customer engagement, so the company needs to create stimuli that are able to influence the social environment to recommend and give positive reviews about the company. The study also identified that sharing information and social interaction have significance but relatively low. And the rest of the variables such as attraction and surveillance did not result in a significant influence on customer engagement. Based on the outcomes on analysis, it is recommended that an Online Travel Agency company concentrates on pursuing social influence, for instance: promotions by influencer and providing complaints and problems assistance in Social Media. With this attitude, social media is not only a necessity but also supporting the company's performance. Especially now that it is proven that 
customer engagement through social media has a high impact on purchase intention, it is important for OTA's to take care of what they post and how they reply messages and comments on their social media to increase the engagement rate with their followers.

This study has some limitations that can be explored more. First, for geographic situation, this research only use Java Island, Indonesia as the scope of research. Next, this research use 200 participants as samples, where maybe next research can have more samples and wider geographical area. We have focused on Online Travel Agency (OTA) in Indonesia, as well as Facebook, Twitter, and Instagram as the social media that is commonly used. For further studies, other social media platforms such as YouTube, TikTok, and LinkedIn can also be the new option for further research. Moreover, future researcher can find some additional variables that can represent customer engagement on social media that most likely will affect purchase intention of OTA.

\section{REFERENCES}

Anubha and Jain, A. (2016). Website Quality as an Antecedent of Customer Purchase Intention for Travel Services: A conceptual model, in Global Information and Business Strategies, 1-10.

Araujo, T. \& Neijens, P. (2012), "Friend Me: Which Factors Influence Top Global Brands Participation in Social Network Sites", Internet Research, Vol. 22, No. 5, 626-640.

Aronson, E., Timothy, D. W., \& \&Akert, R. M. (2010). Social Psychology. Upper Saddle River, NJ: Prentice Hall.

Bandura, A. (1986). Social Foundations of thought and action. Upper Saddle River, NJ: Prentice Hall

Barger, V. A. \& Labrecque, L. I. 2013. An integrated Marketing Communications Perspective on Social Media Metrics. International Journal of Integrated Marketing Communications, 5, 64-76.

Bowden, J. L-H. (2009). The Process of Customer Engagement: A Conceptual Framework.
Journal of Marketing Theory and Practice, 17 (1), 63 - 74.

Brodie, R. J., Ilic, A., Juric, B., \& Hollebeek, L. (2013). Consumer engagement in a virtual brand community: An exploratory analysis. Journal of Business Research, 66(1), 105-114.

Chiu, C. M., Cheng, H. L., Huang, H. Y., \& Chen, C. F. (2013). Exploring individuals' subjective well-being and loyalty towards social network sites from the perspective of network externalities: The Facebook case. International Journal of Information Management, 33, 539-552.

Coyle, J. R., \& Thorson, E. (2001). The effects of progressive levels of interactivity and vividness in web marketing sites. Journal of Advertising, Vol. 30, No. 3, 65-77.

Creswell, John W. (2014). Research Design: Qualitative, Quantitative, and Mixed Methods Approaches. Los Angeles: Sage Publications Inc.

Cummings, Maria, "Consumer engagement perspectives: a tool for ensuring advertising's impact?" (2007). Thesis. Rochester Institute of Technology. Accessed from https://pdfs.semanticscholar.org.

Cvijikj, I. P., \& Michahelles, F. (2011). Monitoring trends on Facebook, paper presented at the IIEE Ninth International Conference on Dependable, Automatic and Secure Computing, December 12-14, Sydney.

Fishbein, M., \& Ajzen, I. (1975). Belief, Attitude, Intention, and Behavior: An Introduction to Theory and Research. Reading, MA: Addison-Wesley.

Fortin, D.R. \& Dholakia, R.R. (2005), "Interactivity and Vividness Effects of Social Presence and Involvement with A Web-based Advertisement", Journal of Business Research, Vol. 58, No.3, 387396.

Gummerus, J., Veronica, L., Weman, E., and Pihlstorm, M. (2012). Customer Engagement in a Facebook Brand 
Community. Management Research Review, 35(9): 857-877.

Ghozali, Prof. Dr. H. Imam, M. Com, Ph. D., \& Latan, Hengky, SE. (2015). Konsep, Teknik dan Aplikasi Menggunakan Program SmartPLS 3.0. Indonesia: Universitas Diponegoro Semarang.

Gummerus, J., Veronica, L., Weman, E., \& Pihlström, M. (2012). Customer Engagement in a Facebook Brand Community. Management Research Review, 35(9), 857-877.

Hall, J. A. (2018). When is social media use social interaction? Defining mediated social interaction. New Media \& Society, 20(1), 162-179.

Humphreys, L. and Wilken, R. (2015). Social Media, Small Business, and The Control of Information. Information, Communication \& Society, 18(13): 295309.

Kelman, H. C. (1958). Compliance, identification, and internalization three processes of attitude change. Journal of Conflict Resolution, 2, 51-60.

Lohtia, R., Donthu, N. and Yaveroglu, I. (2007), "Evaluating The Efficiency of Internet Banner Advertisements", Journal of Business Research, Vol. 60, No. 4, 410418.

Malhotra, A., Malhotra, C. K., \& See, A. (2013). How to create brand engagement on Facebook MIT Sloan Management Review, 54(2), 18.

Marsh, K. L., Richardson, M. J., \& Schmidt, RC. (2009). Social connection through joint action and interpersonal coordination. Topics in Cognitive Science,1(2),320339.

McCulloch, A. (2014). How Social Engagement Drives Site Visits. Retrieved August 13, 2020, from https://www.socialbakers.com/blog/2320how-social-engagement-drives-siteVisits

Mirabi, V., Akbariyeh, H., \& Tahmasebifard, H. (2015). A Study of Factors Affecting on Customers Purchase Intention; Case Study on the Agencies of Bono Brand
Tile in Tehran. Journal of Multidisciplinary Engineering Science and Technology, 267-273.

Muthén, L. K., \& Muthén, B. O. (2002). How to Use a Monte Carlo Study to Decide on Sample Size and Determine Power.

Nyoman, Ni Wira. (2019). Indonesian Travelers Getting More Selective, Google Indonesia Reveals. Jakarta Post. Retrieved July 2020.

https://www.thejakartapost.com/travel/20 19/10/01/indonesian-travelers-gettingmore-selective-google-indonesiareveals.html

Ngai, E. W., Tao, S. S., \& Moon, K. K. (2015). Social media research: Theories, constructs, and conceptual frameworks. International Journal of Information Management, 35(1), 33-44.

Osatuyi, B. (2013). Information sharing on social media sites. Computers in Human Behavior, 29(6), 2622-2631.

Peter, J. P., \& Olson, J. C. (2009). Consumer Behavior and Marketing Strategy Ninth edition. Boston: McGraw-Hill.

Poirier, J., \& Cobb, N. K. (2012). Social influence as a driver of engagement in a web-based health intervention. Journal of medical Internet research, 14(1), e36.

Pütter, M. (2017). The Impact of Social Media on Consumer Buying Intentions. Journal of Marketing, 3 (1), 7-13.

Ridings, C. M., \& Gefen, D. (2006). Virtual Community Attraction: Why People Hang Out Online [Abstract]. Journal of Computer-Mediated Communication, 10(1).

Schroeder, Ralph. 2016. The Globalization of OnScreen Sociability: Social Media and Tethered Togetherness. International Journal of Communication 10(2016), 56265643

Sekaran, Uma. (2003). Research Methods for Business: a Skill-Building Approach 4th Edition. New York: John Wiley \& Sons Ltd.

Sekaran, Uma., \& Bougie, Roger. (2013). Research Methods for Business: a Skill- 
Building Approach 6th Edition. United Kingdom: John Wiley \& Sons Ltd.

Shahbaz, A., \& Funk, A. (2019). Social Media Surveillance. Retrieved August 13, 2020, from

https://freedomhouse.org/report/freedomon-the-net/2019/the-crisis-of-socialmedia/social-media-surveillance

Snijders, R., \& Helms, R. (2014). Analyzing Social Influence Through Social Media, A Structure Literature Review. [Abstract]. International Conference on Information Systems, 1-1.

Sonnenwald, D.H. (2006), "Challenges in sharing information effectively: examples from command and control".

Stafford, T. F., \& Stafford, M. R. (2001). Identifying motivations for the use of commercial Web sites.

Steuer, J. (1992), "Defining Virtual Reality: Dimensions Determining Telepresencell, Journal of Communication, Vol. 42, No. 4, 73-93.

Taylor, A. R. 2019. Attraction Marketing: Bring People to You Rather Than Going After Them. Independently published. p: 3-4.

Thoumrungroje, A. (2014). The Influence of Social Media Intensity and EWOM on Conspicuous Consumption. Procedia Social and Behavioral Sciences, 148, 715.

Whiting, A., \& Williams, D. (2013). Why People Use Social Media: A Uses and Gratifications Approach. Qualitative Market Research: An International Journal, 16(4), 362-369.

Yoong, L. C., \& Lian, S. B. (2019). Customer Engagement in Social Media and Purchase Intentions in the Hotel Industry. International Journal of Academic Research in Business and Social Sciences, 9(1), 54-68.

Zheng, Dawei. 2015. Information Engineering and Education Science: Proceedings of the International Conference on Information Engineering and Education Science (ICIEES 2014), Tianjin, China,
12-13 June, 2014. CRC Press; 1 edition. p: 219. 